\title{
Charles Dickens Post Mortem \& Bare Life Under the New Poor Law
}

\author{
Ruth Richardson
}

King's College London

\section{ABSTRACT}

The theme of this article is how life writing can bury things, sometimes for generations, and how secrets buried in life can re-emerge after death, and disturb. ${ }^{1}$ Lives often make best sense read backwards, so here we start with revelations that emerged only after Charles Dickens's death: in his will, and in John Forster's famous biography and its use of the important document known as the 'autobiographical fragment' written by Dickens himself in the late 1840s. Forster covered gaps in the biography by guiding attention away from certain aspects of Dickens's life, in particular his family's geographical origins. Forster's decisions concerning what secrets could be shared have worked to influence generations of biographers. Recent discoveries have brought fresh light to Dickens's life after both Dickens and Forster had been dead for over a century. Attention is given to why some of these discoveries had not been made sooner, their implications and reverberations, and a fuller understanding is shared of Dickens's fierce antipathy to the cruelties of the workhouse regime under the UK New Poor Law.

Keywords: workhouse, mortality, human dismemberment, predation, mythopoeic biography

\section{DICKENS AFTER DEATH}

After he died unexpectedly in 1870, Charles Dickens was buried in Westminster Abbey rather than at Rochester, closer to his home at Gads 
Hill in Kent as in life he had said he wished. His other funerary directions were respected: a quiet and private ceremony, with only a small number of personal mourners, and none of the customary flummery of Victorian commercial undertaking Dickens so abhorred. A plain black marble horizontal body-stone giving his bare name and the dates of his birth and death marks his tomb in Poets' Corner. ${ }^{2}$

Since Dickens's death the most memorable aspects of his biography have been his secrets-elements of his own life story that he keenly wished to keep hidden for as long as he lived. Three things in particular became widely known only after his death: his father's incarceration in the Marshalsea Prison, the fact that Dickens himself had been a factory boy, and his late relationship with Ellen Ternan.

The first two of these matters were revealed when the first volume of John Forster's great biography of Dickens was published in $1872 .{ }^{3}$ Each was a surprise to contemporaries, and even it seems to Dickens's own children. Dickens had disclosed to Forster that when he was a child the family had to move from north London to Southwark to live inside the Marshalsea debtors' prison where his father was incarcerated as a debtor. Dickens himself had lived outside the prison at that time (1823-1824), earning his own living as a factory boy in a rat-infested London manufactory/warehouse, initially beside the River Thames at Hungerford Stairs and subsequently in Chandos Street (now Chandos Place) between the Strand and Covent Garden Market. Here, to his own shame and embarrassment, the boy Dickens had worked as a sort of living advertisement in the street window dextrously fitting the lids and labels on bottles of shoe-blacking.

Forster's biography preserved silence concerning the disintegration of Dickens's marriage, and left Dickens's relationship with Ellen Ternan a blank. Public knowledge of Dickens's separation from his wife had been widespread in the $1850 \mathrm{~s}$, but the identity of the woman in the case was not. Dickens's closest friends in his later life, including Forster, had known about her, and had assisted Dickens's efforts to preserve her reputation. The sole reference to her in Forster's great three volume biography was in the transcription of Dickens's will, reproduced as an appendix to the end of his third volume of 1874. Gifts to Ellen Ternan during Dickens's lifetime (including a large London town-house) went unrecorded in Dickens's will, but (without specifying their relationship) he had named her as his first legatee. Gladys Storey published her conversations with Dickens's daughter Kate, which verified the love affair, sixty five years later, in 1939. ${ }^{4}$ The painstaking researches of Katharine Longley, Ada Nisbet, and others brought greater clarity to the matter later in the twentieth century. ${ }^{5,6,7,8,9,10}$ 


\section{THE AUTOBIOGRAPHICAL FRAGMENT}

John Forster had known about, and kept silent about, the debtors' prison and the blacking factory for over twenty years: since a particular conversation with Dickens in 1847, the burden of which he related in the biography. ${ }^{11}$ Dickens's parents and other family members had observed a profound silence concerning these matters ever since their occurrence, and Dickens himself seems to have been haunted by them. The conversation in which he unburdened himself to Forster is recognised by scholars as profoundly important for subsequent understandings of Dickens's life and creativity. ${ }^{12}$ Crucially, Forster reported that it had provoked Dickens to create a document which has since become known as the 'autobiographical fragment', and which fed directly into David Copperfield (1849-1850).

At the time of their conversation in 1847, Dickens was the famous author of Sketches by Boz, Pickwick Papers, Oliver Twist, Nicholas Nickleby, The Old Curiosity Shop, Barnaby Rudge, and Martin Chuzzlewit. He was then in the midst of writing the monthly parts of Dombey and Son. Dickens was 35 at the time, and his eldest child had just reached the age of 10 - the same age he had been when his family was faced with their descent into debt. Dickens and Forster had known one another well for over a decade, but this topic had apparently never arisen between them until then. Forster recorded in the biography that during that spring, an issue had emerged during a chat with a mutual friend which led him to pose a question to Dickens, which then set off an unexpected train of events:

I asked if he remembered ever having seen in his boyhood our friend the elder Mr. Dilke, his father's acquaintance and contemporary, who had been a clerk in the same office in Somerset House to which Mr. John Dickens belonged. Yes, he said, he recollected seeing him at a house in Gerrard Street, where his uncle Barrow lodged during an illness, and Mr. Dilke had visited him. Never at any other time. Upon which I told him that some one else had been intended in the mention made to me, for that the reference implied not merely his being met accidentally, but his having had some juvenile employment in a warehouse near the Strand; at which place Mr. Dilke, being with the elder Dickens one day, had noticed him, and received, in return for the gift of a half-crown, a very low bow. He was silent for several minutes; I felt that I had unintentionally touched a painful place in his memory; and to Mr. Dilke I never spoke of the subject again. It was not, however, then, but some weeks later, that Dickens made further allusion to my thus having struck unconsciously upon a time of which he never could lose the remembrance while he remembered anything, and the recollection of which, at intervals, haunted him and made him miserable, even to that hour. Very shortly afterwards I learnt in all their detail the incidents that had been so painful to him. ${ }^{13}$ 
The recollection of these events had led Dickens to begin to write a memoir of his own childhood experiences, the unfinished manuscript of which he subsequently gave to Forster.

It had all been written, as fact, before he thought of any other use for it; and it was not until several months later, when the fancy of David Copperfield, itself suggested by what he had so written of his early troubles, began to take shape in his mind, that he abandoned his first intention of writing his own life. Those warehouse experiences fell then so aptly into the subject he had chosen, that he could not resist the temptation of immediately using them; and the manuscript recording them, which was but the first portion of what he had designed to write, was embodied in the substance of the eleventh and earlier chapters of his novel. What already had been sent to me, however, and proof-sheets of the novel interlined at the time, enable me now to separate the fact from the fiction, and to supply to the story of the author's childhood those passages, omitted from the book, which, apart from their illustration of the growth of his character, present to us a picture of tragical suffering, and of tender as well as humorous fancy, unsurpassed in even the wonders of his published writings. ${ }^{14}$

This uniquely important Dickens manuscript-the 'autobiographical fragment'-has since disappeared. It is not to be found among Forster's papers, nor is it physically identifiable by watermarks or other means within the manuscript of David Copperfield, which has come down to us in Forster's own collection of Dickens manuscripts. Nor is it to be found in any other known archive. The interlined proof-sheets Forster mentions as having been in his possession at the time he was writing the biography also now appear to be lost. ${ }^{15}$

Forster said he knew where the boundaries lay between the life and the fiction in David Copperfield, but for us it seems that the memoir is enfolded so well within the novel that it is now indistinguishable from the fiction itself. The content of the 'autobiographical fragment' has nevertheless survived by assimilation in two forms: by quotation in Forster's biography, and by interfusion within Dickens's fiction. Each form has its own truth, and its own silences.

\section{FORSTER'S SILENCES}

During Dickens's lifetime almost nobody knew the origins of his familygeographically or socially-and both Dickens and Forster separately and in concert appear to have kept the details dark. Friends and relatives chose, or may have been requested, also to remain silent about what they knew. After Dickens's death some information emerged in Forster's 
biography and from the recollections of others, but the cultivation of silence by contemporaries means that it has taken the assiduous labours of generations of Dickensian scholars to assemble the information we now have, which still remains incomplete.

Dickens's paternal grandparents had been upper servants-butler and housekeeper-to an aristocratic family with a grand house near Grosvenor Square. On his mother's side, family members had been wellknown harpsichord makers, with workshops in Cheapside. ${ }^{16,17,18}$ Dickens's maternal grandfather Charles Barrow was for years the 'Chief Conductor and Paymaster of Contingencies' at the Navy Pay Office in Somerset House on the Strand..$^{19}$ Dickens's father John Dickens had worked under Barrow on the staff, where he had met his boss's daughter Elizabeth, and they had married in 1809. But even before the birth of their first child the following year, Charles Barrow had become a fugitive from justice. $\mathrm{He}$ had fled to the Isle of Man after the shocking discovery by the Admiralty that he had embezzled a fortune from the Navy Pay Office-over $£ 5,000$, nearly 400 times a female servant's annual wage at the time. Dickens's parents' wedding, at the church of St Mary-le-Strand, had taken place only a few months before this colossal fraud was made known. The blighting of the couple's prospects caused by Barrow's terrible fall from grace must have impacted upon their economic and social circumstances from the very outset of their family life. ${ }^{20}$

Dickens's father kept his job at the Navy Pay Office, however, for many years. He was eventually pensioned off, and with help from his brother-inlaw John Barrow, a well-established journalist, Dickens senior went on to develop a second career in news journalism. He and Barrow helped young Dickens himself in his early career as a shorthand writer and journalist.

John Forster is an excellent source of information in many respects: much of the data we have concerning Dickens's life is either presented in his book, or clues towards it appear there. But Forster also steered readers' attention so as to conceal certain things. Some of these efforts may screen gaps in Forster's own knowledge. Recent discoveries include Dickens's father's christening in Marylebone, as well as the date of his younger sister Harriet's death and her place of burial in a small graveyard near Marble Arch. ${ }^{21,22}$ Others of Forster's silences appear intentional, and are likely to have been agreed with Dickens himself, perhaps directed by him. Forster's narrative emphasis on Dickens's birth in Portsea and his childhood in Chatham obscures the fact that each of Dickens's parents had strong roots in central London, and that Portsea and Chatham had been only brief episodes in their lives.

The manner in which Forster reported Dickens's early life has markedly influenced perceptions of Dickens's origins. Until quite recently, little 
emphasis had been placed by biographers on how much of a London boy the novelist really was, either by origin or settlement. It is now known that Dickens's parents had each been born and raised in London, had met and married in London, and had each died and were buried there. They had spent eight years away during their son's childhood because John Dickens's work for the Navy Pay Office during and after the Napoleonic Wars took him to postings in the dockyards at Portsea and, later, at Chatham. The young couple may have welcomed the first absence from the London office after the exposure of the great fraud, and were probably glad of the extra pay granted to staff posted to port work. But after two years in Portsea they returned to London and spent the following two years living in Marylebone, close to one of Mrs Dickens's aunts, a skilled piano-string maker. ${ }^{23}$ After the second port posting to Chatham they swiftly re-established themselves back in London, this time in the adjacent parish of St Pancras, and they remained in the same general area of north London for most of the rest of their lives.

Forster's account slides over the two years in London between these two port jobs almost imperceptibly:

When his father was again brought up by his duties to London from Portsmouth, they went into lodgings in Norfolk Street, Middlesex Hospital; and it lived also in the child's memory that they had come away from Portsea in the snow. Their home, shortly after, was again changed, on the elder Dickens being placed upon duty in Chatham dockyard [... $]^{24}$

The period in London was the same duration as that in Portsmouth-two years-but Forster presents it as briefer and much less significant, while yet providing the crucial detail of the London street in which they had lodged. That the family had returned to the same Norfolk Street address at a later stage for an even longer period, and had remained attached to the bohemian district straddling the St Pancras/Marylebone border thereafter, is something Forster did not mention. Nor did he vouchsafe that Dickens's father had been christened locally, and that while Dickens was growing up there, relatives lived close by.

By the time Forster's biography was published in the 1870s, the place in which the Dickens family had twice lodged had been doubly obscured. The street-name of Norfolk Street had disappeared from maps of the area. It had been absorbed into the much longer Cleveland Street, which now stretched north from Goodge/Mortimer Street right up to the Marylebone Road, then known as 'the New Road'. When it became part of the longer street, the house had also been re-numbered.

Although a Marylebone address carried a certain cachet, the particular part of that parish the family inhabited in Dickens's childhood and 
teenage years had been profoundly unfashionable ever since it had been newly built in the fields north of Oxford Street in the late eighteenth century. Norfolk Street occupied the extreme eastern edge of Marylebone, adjoining the southernmost sliver of St Pancras parish, and almost adjacent to the notoriously rough and overcrowded parish of St Giles. Norfolk Street stood in a downmarket area between a street market and a somewhat seedy theatre (since demolished) parallel to the eastern flank of the Middlesex Hospital - a charitable institution for the sick poor. Although the area had a bohemian atmosphere of creative, artistic and theatrical industry, Norfolk Street also had a recurrent history of prostitution. What is more, a large central London workhouse stood on the next block north. So although its location in Marylebone masked this to a degree, Norfolk Street was a very long way from being a 'desirable' address in London. ${ }^{25}$

During his lifetime, Dickens may have had his own reasons for not wanting to be identified with this neighbourhood. Norfolk Street occupied social as well as geographical margins; knowledge of his childhood association with this hinterland would also have located him as socially contiguous to St Giles's or Seven Dials. Concern about being sullied with low plebeian origins might also have been coloured by the danger that people still living in Norfolk Street may well have known about the Marshalsea, or some other embarrassing episode involving his father's debts the family hoped to keep dark.

The strength of his parents' ties to the area is shown by his father's name in the baptismal ledger at Marylebone Old Church, and the number of addresses his family occupied in the Marylebone/St Pancras vicinity. A tabulated chronology is given here of most of the various addresses known to have been lived in by Dickens and his family up to the time he finally left the parental home in Marylebone at the age of 22 to take up his own rented accommodation as a young professional (see Table 1).

The table (which does not detail brief periods in other lodgings) shows the high number of removals the family underwent-a characteristic propensity among those on the margins of poverty. Multiple moves could be prompted by any number of factors, such as the need to follow work, a desire for better or cheaper accommodation, to re-establish after eviction, to evade creditors, or to make hurried 'moonlight flits' while owing rent. The table demonstrates the significance of the Norfolk Street location. The family's return to Marylebone signified a return to equilibrium after the catastrophic plunge into imprisonment for debt and the gradual recovery of its fortunes.

Forster followed the Dickens family's peregrinations from Portsea to London and Chatham, and back to London's Camden Town and Gower Street, opposite University College's great portico. Then into the Marshalsea prison, their subsequent return to Somers Town and-after the blacking factory-young Dickens's attendance at Wellington House 
Table 1: The Dickens Family's Main Known Addresses Before $1834^{26}$

\begin{tabular}{|c|c|c|c|}
\hline \multicolumn{4}{|l|}{ (Age) } \\
\hline Dickens born & 1812 & 16 Hawke Street, Portsmouth & CD born, baptized at Portsea \\
\hline 1 & 1813 & Wish Street, Southsea & \\
\hline 2 & 1814 & Wish Street, Southsea & \\
\hline 3 & 1815 & $\begin{array}{l}10 \text { Norfolk Street, Marylebone (now } 22 \text { Cleveland } \\
\text { Street) }\end{array}$ & \\
\hline 4 & 1816 & 10 Norfolk Street, Marylebone & \\
\hline 5 & 1817 & Sheerness, then Ordnance Terrace, Chatham & \\
\hline 6 & 1818 & Ordnance Terrace, Chatham & \\
\hline 7 & 1819 & Ordnance Terrace, Chatham & \\
\hline 8 & 1820 & Ordnance Terrace, Chatham & \\
\hline 9 & 1821 & St Mary's Place, Chatham & \\
\hline 10 & 1822 & 16 Bayham Street, Camden Town, St Pancras & \\
\hline 11 & 1823 & $\begin{array}{l}4 \text { Gower Street North, St Pancras (facing University } \\
\text { College) }\end{array}$ & \\
\hline \multirow[t]{3}{*}{$11-12$} & $1823 / 4$ & FATHER ARRESTED FOR DEBT & $\begin{array}{l}\text { CD in BLACKING FACTORY Hungerford Stairs, } \\
\text { then Chandos Street, Covent Garden }\end{array}$ \\
\hline & & FAMILY IN MARSHALSEA DEBTORS' PRISON & $\begin{array}{l}\text { CD lodging in Little College Street, St Pancras, } \\
\text { then Lant Street, Southwark }\end{array}$ \\
\hline & & then Johnson Street, Somers Town, St Pancras & $\mathrm{CD}$ at school: Wellington House Academy, Mornington Crescent \\
\hline 13 & 1825 & Johnson Street, Somers Town, St Pancras & CD at school: Wellington House Academy \\
\hline 14 & 1826 & Johnson Street, Somers Town, St Pancras & $\mathrm{CD}$ at school: Wellington House Academy \\
\hline 15 & 1827 & $\begin{array}{l}\text { ?Family evicted from Johnson Street, St Pancras } \\
\text { then lodgings in } 17 \text { Polygon, St Pancras }\end{array}$ & CD Clerk at Inns of Court \\
\hline 16 & 1828 & ?Johnson St ... then 10 Norfolk Street, Marylebone & CD Freelance reporter \\
\hline 17 & 1829 & 10 Norfolk Street, Marylebone & CD Freelance reporter \\
\hline 18 & 1830 & 10 Norfolk Street, Marylebone & CD Freelance reporter + new Reader at British Museum \\
\hline 19 & 1831 & 10 Norfolk Street, Marylebone & CD Freelance reporter \\
\hline 20 & 1832 & $\begin{array}{l}10 \text { Norfolk Street, Marylebone } \\
\text { then elsewhere close by }\end{array}$ & CD Reporter on Mirror of Parliament + True Sun newspaper \\
\hline 21 & 1833 & 18 Bentinck St, Manchester Square, Marylebone & CD's First sketch published \\
\hline 22 & 1834 & $\begin{array}{l}\text { CD moves to Furnival's Inn, High Holborn } \\
\text { LEAVES FAMILY HOME PERMANENTLY }\end{array}$ & $\begin{array}{l}\text { CD Salaried reporter on Morning Chronicle newspaper } \\
\text { CD's 1st pieces signed 'Boz' }\end{array}$ \\
\hline
\end{tabular}

school. But Forster did not mention the Dickens family's eviction from their home in Johnson Street. Neither did he draw his readers' attention to the fact that the family spent longer in eastern Marylebone than in any other part of the world, nor that Charles Dickens's return to paid work in 1827 may actually have been what allowed them to return there. Nor did Forster emphasise that for most of his later successful adult life Dickens chose upmarket homes in the same general vicinity: the border areas of St Pancras and Marylebone.

Instead, Forster chose another route, diverging away from the family's housing by tracing Dickens's life from school to his first workplace, and to his subsequent successful employment at Doctors' Commons (near St Paul's Cathedral) then on to Westminster as a Parliamentary reporter, and his work as a newspaper reporter. He picked up again on Dickens's living accommodation only after he had left the parental home in Marylebone to live independently at Furnival's Inn (High Holborn), and then the move to his first married home in Doughty Street. By turning to follow 
Dickens's working career, Forster directed attention away from the shabby margin of Marylebone near St Giles's, and laid his emphasis instead upon Dickens's first 'respectable' addresses. William Fredeman has characterised this kind of biographical manipulation as 'mythopoeic distortion', and explains that it is accomplished 'not by fabricating events but by telling less than the whole truth, by the skillful selection of documentation, by the purposeful shading of inference, and by the careful manipulation of emphasis'. ${ }^{27}$

\section{CLEVELAND STREET}

Forster's mythopoeic distortion of Dickens's early life obscured the fact that Dickens possessed a detailed and intimate knowledge of Norfolk Street, Marylebone and its environs from having lived there as a child, as a teenager and as a young man. Young 'Boz' had passed almost a quarter of his life within the sensory and affective penumbra of the adjacent busy workhouse, its sounds, smells, and the many human objects of pity that frequented its vicinity. From infancy, Dickens also had access to the local knowledge of older relatives and neighbours long settled in the district. The street was not just a location or a backdrop, it provided source material for more than one of his books: it was a source of inspiration, a shaping element in Dickens's life and fiction. ${ }^{28}$ Subsequent Dickens scholars and afficionados overlooked the significance of the vicinity because Forster's swerve to Dickens's occupational biography put them off the scent: they were effectively manoeuvred by Forster's working turn. The same divergence is evident in all extant biographies which draw their sustenance from Forster.

Biographers had known that Dickens had lived at 10 Norfolk Street, and that the street had been absorbed to become the southernmost part of Cleveland Street. But none of them seems to have noticed that a busy London workhouse stood on the next block. A simple explanation of this oversight may be found in the fact that Dickens scholars seeking to identify the actual house in Norfolk Street in which Dickens had lived with his parents and siblings would have used a unique map of the parish of Marylebone, created by Peter Potter in $1820 .{ }^{29}$ This map has one highly valuable characteristic: it was executed in such close detail that it recorded the house number of each building in every street in the parish. The same map shows that the boundary of Marylebone parish passed centrally down the entire length of Cleveland Street, until it swerved to the south-east to pass immediately behind Norfolk Street on its way towards St Giles. 


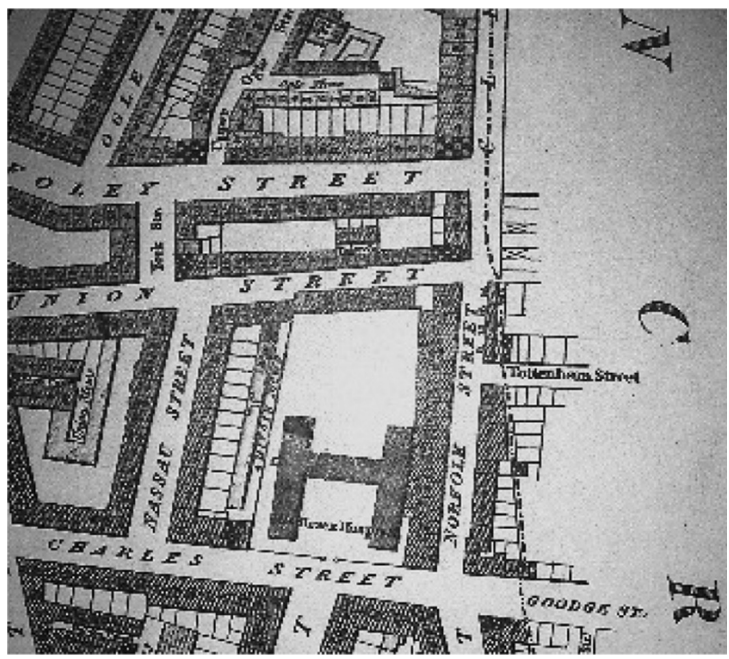

Figure 1: Detail from Potter's Map of Marylebone (1820). Reproduced courtesy of Westminster Archives.

This superb map would have allowed Dickens scholars to locate the building in which the Dickens family had lived: a small Georgian house which stood-and happily still stands-just within the Marylebone boundary on the south-east corner of the junction with Tottenham Street. A St Pancras parish marker from the 1830s still shows on the adjoining house in Tottenham Street today.

Yet no-one could have guessed from this map that one of London's principal workhouses stood just north of the same junction. The Cleveland Street Workhouse had been built in the fields in the 1770s, originally to serve the poor population of Covent Garden parish, the same parish in which the second Blacking Factory stood. After the enactment of the New Poor Law in 1834 the workhouse became the Strand Union Workhouse, serving all the main parishes along the length of the Strand. It stood just outside the parish boundary of Marylebone and within the parish of St Pancras, so its site-like the remainder of the adjoining parishesappears as a blank on Potter's map.

The parish boundary-line passes along the rear wall of Dickens's home, on the south-east corner of Norfolk Street and Tottenham Street. The Cleveland Street Workhouse site occupies the blank area above the dark horizontal line opposite Foley Street on the map, a few doors up from Tottenham Street. The large 'H' shaped building 
shown on the map is the Middlesex Hospital. Charles Street is now Mortimer/Goodge Street. Dickens's Aunt Charlton lived in Berners Street, which opens opposite the Hospital. Ellen Ternan was established in lodgings in Berners Street soon after Dickens's separation from his wife in $1858 .{ }^{30}$

In the 1980s I had co-written a paper on the life and work of the great workhouse reformer, Dr Joseph Rogers-the only Poor Law doctor in England who left a published memoir, much of which concerns his working life inside the Cleveland Street Workhouse. ${ }^{31}$ At that time, the Workhouse building was still in use as the National Health Service Outpatients' Department of the Middlesex Hospital, as it had been for many years. ${ }^{32}$ In 2010 a local woman hoping to preserve the Workhouse from demolition had found my paper on the internet and tracked me down. Dr Rogers did not seem to have known that Dickens had twice lived on the next corner, and nor did I, until I had searched out the addresses shown in Table 1. For some unknown reason Dickens's childhood home had never been marked with a plaque, so its identity was not manifest. ${ }^{33}$ The close contiguity of these two surviving buildings, Dickens's home and the Cleveland Street Workhouse-and the potential importance of this street to Dickens's life and work-suddenly assumed great importance.

Until 2011, no-one had satisfactorily shown that any specific workhouse might have influenced or inspired Dickens to write so knowledgeably about the workings of the Poor Law, nor had it been satisfactorily explained why Dickens had chosen to write such a novel as Oliver Twist so early in his career, parallel with the concluding numbers of his first book, Pickwick Papers. Within the narrow window of only five weeks available to us to save the building from destruction, enough evidence was found to demonstrate that the Cleveland Street Workhouse was likely to have been the key institution behind Oliver Twist: the model for the most famous workhouse in the world.

The Friends of the Cleveland Street Workhouse managed to delay the planning decision concerning demolition, and built an international awareness of the historical importance of the whole site, and of its vulnerability. Happily the delay enabled the assembly of further evidence to verify the inference that a significant location had indeed been found for this iconic work of British fiction. Most importantly, documentary confirmation was found in Dickens's earliest known calling card, which features the Norfolk Street address. ${ }^{34}$

Dickens's youthful application for his Reader's Ticket at the British Museum was made from this address, as were several consecutive renewals..$^{35}$ Another new discovery of critical significance in the identification of the 


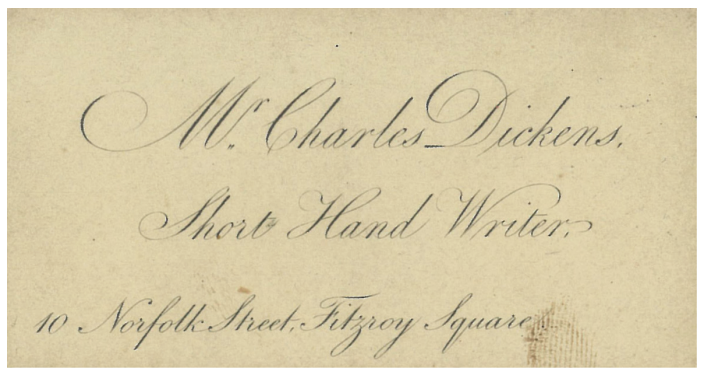

Figure 2: Young Mr Dickens's Calling Card.

Courtesy of Dan Calinescu, Boz and Friends Books, Toronto.

Cleveland Street Workhouse as crucial to Dickens's novel Oliver Twist, was that one of many private signifiers with which Dickens peppered his fictions included the name he chose for its murderous villain. A man whose shop faced the Cleveland Street Workhouse at the time Dickens was writing the novel was named-yes-William Sykes. ${ }^{36,37}$

Until 2017 it seemed the historic workhouse and its site might be saved, but sadly both English Heritage and Camden Council failed to preserve it, and the developers finally got their way. All that is to be kept on the site is the workhouse facade, which is to be gutted for upmarket apartments. The remainder, which includes the deep fabric of its unique historyfrom the eighteenth century Old Poor Law era right up to the modern National Health Service in the early twenty-first-is being obliterated as I write. The site encompassed two superb Nightingale pavilions which had miraculously survived the London Blitz, in the design of which Florence Nightingale herself had a hand and an intense practical interest. ${ }^{38}$

The fate of the bodies of the poor souls still lying in the deep burial ground surrounding the workhouse building has yet to be satisfactorily addressed. The entire site, but for the original workhouse footprint, had been consecrated for burial in 1790 by Bishop Beilby Porteous. Thousands of burials took place there. ${ }^{39} \mathrm{An}$ apparently assiduous silence surrounds the matter in the planning applications. The Church of England has done nothing to assist.

\section{THE POOR LAW AND 'BARE LIFE'}

In Oliver Twist Dickens openly addressed the despicable level of institutionalised neglect and predation that was allowed to flourish within the 
Poor Law system. Funding was pared to the bone, yet the 'farming-out' of the infant poor to the so-called care of private contractors served to generate profit to the contractors, and illness and often death to children in the grip of a cruel and ugly system. ${ }^{40}$

Whilst Dickens had been actively pondering the sequel to Pickwick, in 1836 a London doctor, Thomas Pettigrew, had published a courageous and principled remonstrance against the pauper farming system then being used against the children of the parish of St James Piccadilly. ${ }^{41}$ Pettigrew had served at the inquest of a young boy, George Coster, who had died after being 'farmed out' at a privately-owned pauper 'farm' in Norwood, to which the poor children of St James's parish were sent.

Pettigrew had discovered that these children-most of them under the age of ten-were routinely held prisoner in a shockingly harmful regime of neglect and effective starvation. This 'farm' was essentially a small concentration camp for the infant poor. Pettigrew witnessed and recorded the overcrowding - three children to a bed, ninety to a confined and airless room-the dirt and insanitation, the apallingly depleted diet. He could find no particle of fat-tissue anywhere on George Coster's emaciated corpse. In his examination of other poor children from the same premises, Pettigrew diagnosed a number suffering from 'mesenteric disease'-fatal mesenteric necrosis, or disseminated tuberculosis of the intestine-acquired since they had been moved from the parish's previous branch facilities in Wimbledon to the cheaper private contractor's 'farm'. Pettigrew warned that the unventilated overcrowding at Norwood and the starvation diet there would inexorably spread mortal disease to other malnourished and neglected children then in the establishment. These children were effectively under sentence of slow death. ${ }^{42}$

In Oliver Twist Dickens compares the fate of two parish orphans: Oliver, who runs away to escape the Poor Law system, and Little Dick, who remains behind, only to die of maltreatment and starvation under the joint ministrations of the profiteering Mrs Mann the baby-farmer and Mr Bumble the parish beadle. The children in Mrs Mann's branch workhouse have a net mortality of 85 percent. $^{43}$

Dickens lived long before 'bare life' had been formulated by Giorgio Agambem as a philosophical notion to characterise the power sovereign states assume over the lives of individuals: the capacity to dictate who may live and who must die. ${ }^{44}$ Dickens was, however, aware that the high mortality in these places was profitable: he shows in Oliver Twist that even dead paupers lined contractors' pockets..$^{45}$ Like Thomas Pettigrew, Dickens perceived that the rapacious predation and peculation fostered 
by the Poor Law system served to generate death among those in its grip: the Poor Law was effectively being used a covert means of genocide.

The workhouse in Cleveland Street had a secure front gatehouse, above which was displayed a statue of an old man pointing to an inscription: 'AVOID IDLENESS AND INTEMPERANCE'-the inference being that all who entered there were lazy drunkards.$^{46}$ Contemporaries were aware that the primary reasons poor people entered workhouses were illness and old age, and that because no funds existed for professional nursing in these places 'able-bodied' inmates were needed to nurse them. There was no welfare provision outside the Poor Law, and most of the people dependent on the Poor Law were what we would now recognise in other terms: the 'infirm elderly' would now be pensioners and veterans, frail elderly or terminally ill patients; the 'sick poor', NHS hospital patients; 'crippled and maimed' we perceive as people with serious disabilities; 'insane paupers' as mentally ill. 'Pauper infants' we would recognise as the vulnerable young. Hectoring propaganda such as the inscription over the workhouse gate in Cleveland Street would have a later, more developed iteration, infamous in the succeeding century and belonging to a different and more effectively vicious utilitarian regime: the iron sign 'Arbeit Mach Frei' ('Work sets you free') over the entrance to Auschwitz. ${ }^{47,48}$

In Cleveland Street under the New Poor Law poor families were split apart. Men were sent to one side of the institution, women to the other, and further means of meeting denied. Procreation was to be prevented at all costs. Any residual possessions were sold for the benefit of the institution. New inmates were forced to remove whatever clothing they had, to undergo an enforced communal bath, and to don the workhouse uniform. Heads were routinely shaved, ostensibly to prevent parasitic livestock, such as hair and body lice. The uniform and the shaved scalp also served as stigmata in the event of escape. Children were sent seven miles away to Hendon, their mothers specifically forbidden from serving there as nurses. Older children were 'apprenticed out' to people like Sowerberry, the obnoxious parish undertaker in Oliver Twist. Unpaid forced labour was daily exacted from every inmate in exchange for food, the work overseen by a taskmaster incentivised for rigour by a profit-share of inmates' productivity. Forster's biography gives no indication whatever that Dickens had lived beside this gulag for five years of his childhood and youth.

The workhouse diet (tabulated and distributed by Edwin Chadwick, Jeremy Bentham's right-hand man and the assiduously busy Secretary of the Poor Law Commission at the time) was designedly worse than any local labourer's diet. ${ }^{49}$ Inmates were left with the cheapest gruel, the thinnest broth, the roughest bread, and no 'extras' whatever to prevent 
scurvy. ${ }^{50}$ The printed workhouse regulations at Cleveland Street twice restated a rigid ban on second helpings. ${ }^{51}$ Contact with the outside world was made deliberately difficult, writing materials off limits. ${ }^{52}$ The workhouse system extracted people from their communities and corralled them separately from the rest of the world behind high walls and gates, and the workhouse graveyard. These were indeed camps, in Agamben's sense. ${ }^{53}$ To enter the workhouse was effectively a form of incarceration, with poverty the crime.

Ajournalist in the mid-1830s, Dickens looks to have known of Pettigrew's remonstrance against the mortal cruelty in operation at Norwood, and also of what was afoot at the Strand Union Workhouse in Cleveland Street at the time. Oliver famously transgresses the workhouse rules by asking for more to eat, having been coerced into courage by the fearful hunger of other pauper boys-one of whom had threatened to eat one of his fellows if the demand for more food failed. The cannibalism storyline in Oliver Twist was specifically aimed at the Poor Law starvation diet, and the hungry child's statement of want-'Please sir, I want some more'-at the reiterated official prohibition of second helpings of workhouse food in the regulations.

George Cruikshank's famous image of Oliver asking for more shows other boys in the background with heads shaved, and gaunt from want. The scrawny pauper helper reacts fearfully, knowing Oliver's unwise temerity will provoke merciless punishment from the stout workhouse master, as indeed transpires. ${ }^{54}$

The punishment regime, the stinted diet, and the lack of education provided for these children is elaborated in the book's storyline of the character Little Dick. To Mr Bumble's consternation, and Mrs Mann's horror, the illiterate child-emaciated from advanced malnutrition, and aware that he is dying - asks for someone to write down his last wishes, to be read after he is laid in the earth. Mr Bumble surveys the child from head to foot with 'indescribable astonishment', and orders him out of his sight. The child is never seen alive again. ${ }^{55}$ The dying child's loving concern for Oliver's survival, his own desire for death, and his hope of meeting his dead sister in heaven, is given in full in the text of Oliver Twist. Dickens took it upon himself to serve as Little Dick's amanuensis, to become the workhouse whistleblower. ${ }^{56}$

Also in 1836, Augustus Welby Pugin published his extraordinary Contrasts - a broadside against what its author saw as the utilitarian cruelty and ugliness of the age.$^{57}$ The large illustrative plates Pugin created for the book compare past and present: one shows a mediaeval monastery and a contemporary panopticon workhouse, deliberately contrasting the kindness of ideal Christian care provided to the poor by the brothers, as 


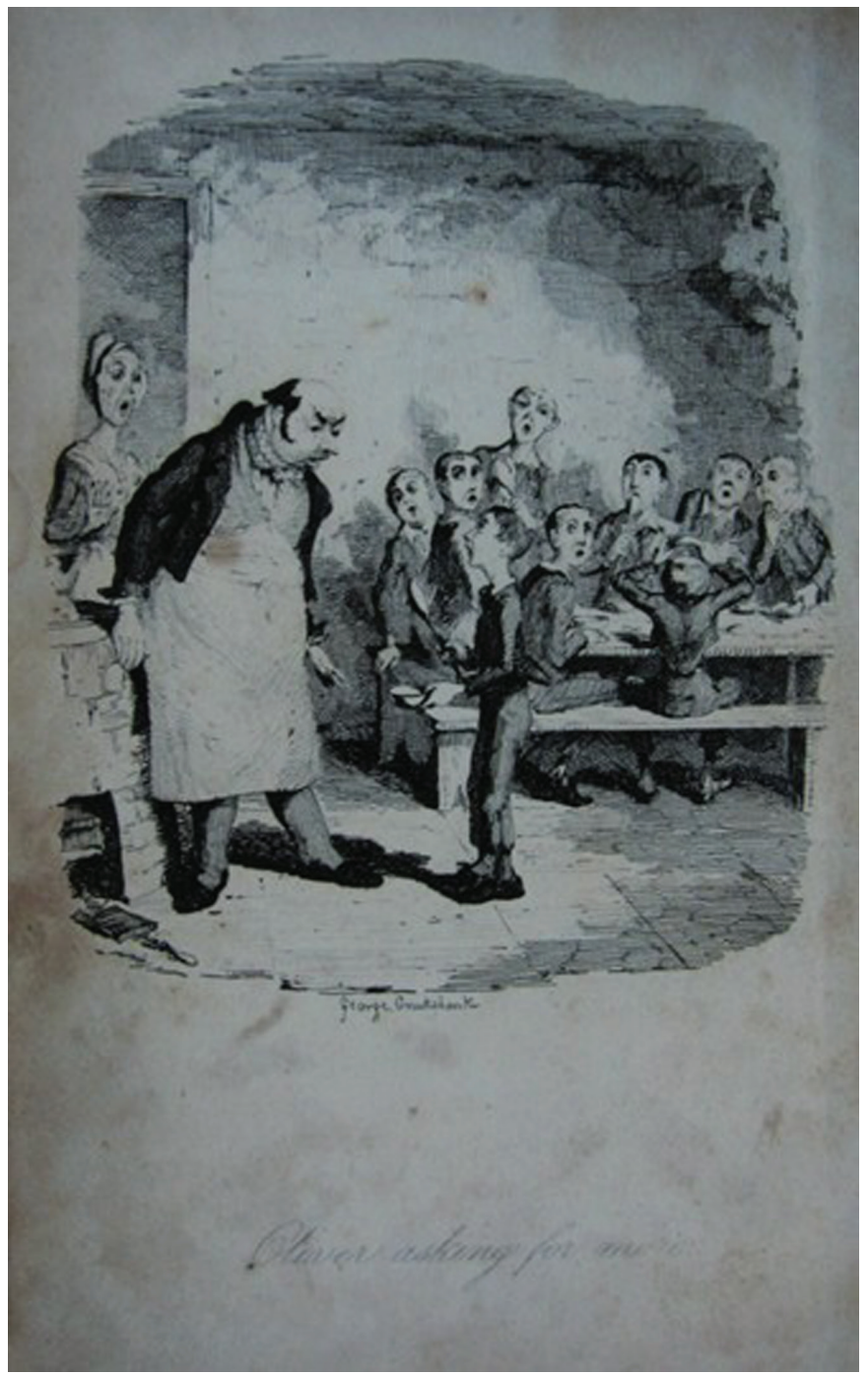

Figure 3: 'Oliver asking for more' (1837) by George Cruikshank. Reproduced courtesy of Dan Calinescu, Boz and Friends Books, Toronto.

against the very different kind of 'care' then on offer under the Benthamite New Poor Law: incarceration, starvation diet, sadistic discipline and-in place of Christian burial-enforced dismemberment. Pugin regarded the Poor Law as fundamentally un-Christian. In one vignette he explicitly 
elaborated the fate of those who died in the workhouse after the 1832 Anatomy Act. Captioned 'The Poor Man's Convoy', it shows a corpse on a board raised on trestles, coffins labelled 'FOR DISSECTION' and men shamefacedly shifting them for onward transport. A coiled rope hanging on a wall-hook behind this scene could be a noose or a whip, reminding the viewer both of slavery and of the law before 1832, which had consigned only hanged murderers to dissection. An explanatory notice states: 'A VARIETY OF SUBJECTS ALWAYS READY FOR MEDICAL STUDENTS' ${ }^{58}$

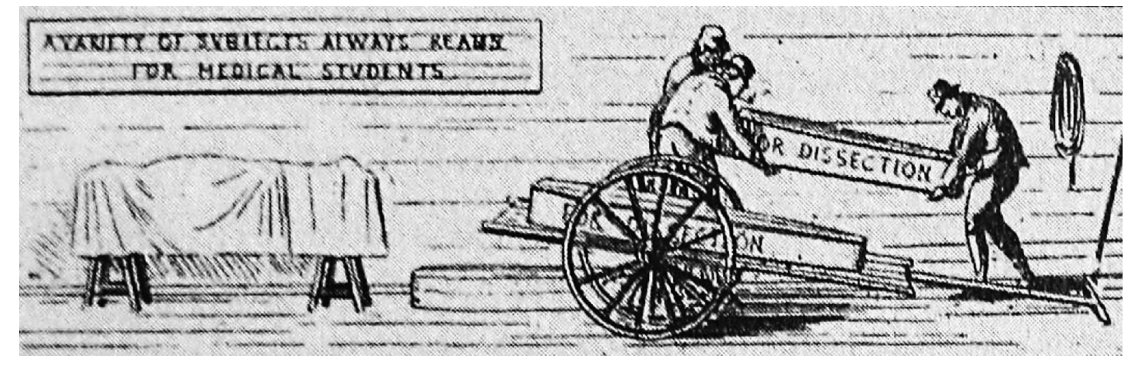

Figure 4: ‘The Poor Man's Convoy', vignette from Augustus Welby Pugin's Contrasts (1836). Courtesy of James Stevens Curl.

In Oliver Twist Dickens, too, addressed the Anatomy Act. Early in the book, he shows the undertaker and Mr Bumble companionably sharing the contents of a snuff box in the form of a patent coffin (a specially designed iron coffin to protect the wealthy dead from being graverobbed for dissection), demonstrating their own comfortable safety from that fate, while mulling together the lucrative business of disposing of paupers' remains. ${ }^{59}$ At the heart of the book, Chapter 24 deals with the death inside the workhouse of Old Sally, the inmate who had laid out the body of Oliver's mother who had died giving birth to him in the workhouse in the novel's opening pages. The fate of Old Sally's body is specified in the chapter's title, 'on a very poor subject', referring not just to a distasteful topic or a low subaltern of Queen Victoria, but a commonly used term for a corpse for dissection.

At the book's conclusion, the final illustration depicts Oliver and his maternal aunt Rose Maylie standing before a monument commemorating Oliver's mother Agnes. Contemporaries would have understood immediately what Dickens meant when he stated in the book's final lines: 
'There is no coffin in that tomb' ${ }^{60}$ His clear implication worked to remind his readers of Oliver's mother's pitiful death, and the destruction of her body by dissection. The empty tomb at the book's end casts the entire story back to its terrible beginning inside the workhouse, where the dying woman had relinquished her nameless baby into parish hands, and where the locket which would identify him was stolen from her corpse. ${ }^{61}$

\section{SUBTERRANEA}

The year before Dickens started writing Oliver Twist a brand new medical school had been erected immediately behind the pawnbroker's shop diagonally opposite Dickens's home in Norfolk Street. It was a textbook location for a new anatomy theatre, dissection room and museum: at the rear of the Middlesex Hospital's garden, convenient to the Hospital, but additionally designed to take advantage of the flow of workhouse dead from across the road. A tunnel was later constructed between the two institutions, which allowed the volume of traffic to become less visible. ${ }^{62}$

No-one in the novel-apart perhaps from Mr Sowerberry the undertaker-possesses any knowledge concerning the ultimate resting place of Agnes's bones. Under the corpse distribution system organised by the Anatomy Inspectorate, those who died in the Cleveland Street Workhouse would have been carried to the new Medical School opposite, or to other London medical schools further afield. The ultimate fate of their remains was not a matter for particular oversight. ${ }^{63}$

According to the law, the remains of people dissected under the Anatomy Act should have been decently buried in consecrated ground. A recent discovery shows that such burials could in fact be huggermugger. In 2010, dissected human remains were accidentally unearthed a few blocks east of Cleveland Street, in the great forecourt of University College London-an open space attached to what was referred to in the nineteenth century (allegedly by the Duke of Wellington) as 'that Godless Institution on Gower Street'. ${ }^{64}$ A six foot (1.8 metres) trench had been dug in the lawn to accommodate some new fibre-optic cables, but work had to be suspended when a jumbled mass of thousands of bones and bone-fragments was revealed. It subsequently emerged that the trench had yielded the dismembered and dissected remnants of nearly 90 individuals, intermixed with animal bones. The remains were described as the residue of a 'Victorian teaching collection', since they exhibited signs of having been cut with scalpels and saws, and/or written upon. ${ }^{65}$ The stratum of soil in which they lay currently continues unexplored under the unconsecrated grassed area of UCL's great quadrangle facing onto Gower Street-the great portico of which protects the body of Jeremy 
Bentham, the architect of Utilitarianism and of the Anatomy Act, whose dressed skeleton or 'Auto-Icon' sits honoured in its glass case upstairs. ${ }^{66,67}$

No-one in authority at University College could explain the derivation of the human remains in the forecourt, when or how they had arrived there, nor how extensive the deposit might prove to be. Yet the source of these remains is not arduous to surmise for anyone with knowledge of the College's history-for many years the College's own medical school stood facing the College colonnade from the other side of Gower Street. In the pre-Anatomy Act era medical school basements were designed to be accommodating, so these human remains probably date to the nineteenth century and had previously formed a burial layer at sub-basement or below cellar-floor level within the old UCL medical school, founded in 1834, shortly after the enactment of the Anatomy Act (see Table 2). The bones were most likely secreted in the College quadrangle during some past process of rebuilding or reconfiguration of the medical school's lower levels. ${ }^{68}$ While many of those dissected at UCL were probably patients from its own hospital mortuary, it is very likely that numbers of these jumbled bones belong to people who had died a few blocks away in Cleveland Street, or in more distant workhouses, brought to Gower Street for dissection under the Anatomy Inspectorate's pauper corpse distribution system. ${ }^{69}$

These long-concealed and sorry scraps of the dismembered Victorian poor have become a 'collection' again, and are to be used 'to teach current medical, forensic and science students' ${ }^{70}$ Forced requisitions decreed under the bare-life policies in force in Dickens's lifetime are thus reinscribed upon our own era. Present day archaeologists, pathologists and museum curators, professionally trained to regard these residues of wronged humanity as 'finds', seem unable to perceive their own role in the continued control of the afterlives of the powerless, their own collusion with the politics of 'bare life'.

Official amnesia has apparently operated with equal efficiency in Cleveland Street. The names and burial location records kept nationally of all those poor individuals requisitioned under the Anatomy Inspectorate and distributed for dissection among the London medical schools are lost, probably destroyed. The Covent Garden parish records for burials specific to the consecrated ground surrounding the workhouse in Cleveland Street have also disappeared. Yet we know bodies went across the road from the Cleveland Street Workhouse for dissection at the Middlesex Hospital Medical School, and that the pauper graves behind the workhouse itself were very deep. ${ }^{71}$ Thousands of individuals were buried in the consecrated ground at Cleveland Street Workhouse, but it features not a single monument. ${ }^{72}$ 


\section{DEATHLY VITALITY}

The threatened destruction of the Cleveland Street Workhouse and the desecration of its consecrated burial ground has resulted in a reconsideration of the life of Charles Dickens, one of England's most celebrated novelists, and of his famous novel Oliver Twist. A new recognition of the geographical and social influences on Dickens's imagination has been engendered by the discovery of the relationship between this street, his life and the novel. Dickens's writing forcefully engaged with the Utilitarian politics of the time: his novel can be understood as the powerful intervention of a political activist with profound personal knowledge of the lives of the London poor.

Table 2: Chronology

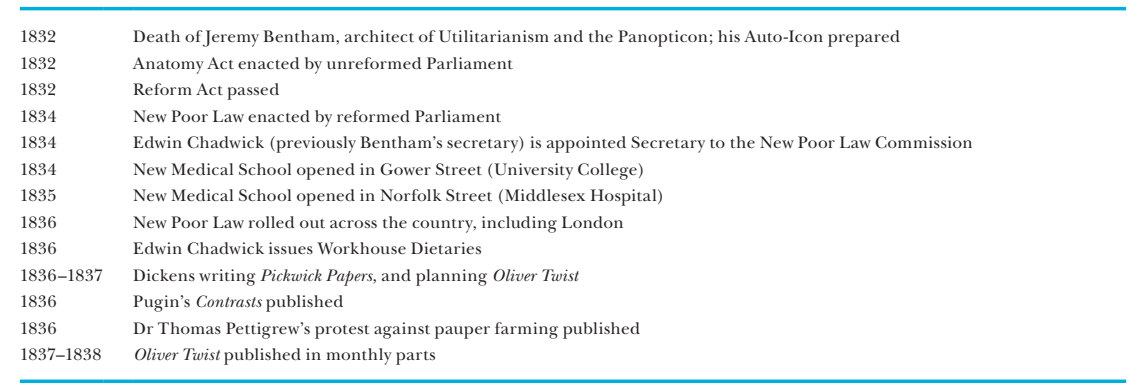

Recent researches concerning Charles Dickens's childhood and young manhood in the Marylebone/St Pancras area of London have enriched our understanding of his life and of his fiction. They reinforce recognition that his project in Oliver Twist was to demonstrate the illegitimacy not of parish children but of the vicious and irresponsible ruling elite, which had knowingly created a system of closed institutions to manufacture human abjection, from cradle to grave. These discoveries also throw into sharp relief the silences of Dickens's biographer John Forster, and the manner in which-from the time of its first publication to our own-his mythopoeic biography has shaped perceptions of Dickens's life.

In a letter of public support for the establishment in 1866 of the new Association for the Improvement of London Workhouse Infirmaries, Charles Dickens wrote:

My Dear Sir,

My knowledge of the general condition of the Sick Poor in workhouses is not of yesterday, nor are my efforts in my vocation to call merciful attention to it. Few anomalies in the land are so horrible to me as the unchecked existence of many shameful sick 
wards for paupers, side by side with a constantly recurring expansion of conventional wonder that the poor should creep into corners to die, rather than fester and rot in such infamous places. ${ }^{73}$

Dickens's letter, with its commitment of funds to help establish the Association, was read aloud by the workhouse doctor Joseph Rogers to repeated cheers from the audience at the Association's inaugural meeting, in March 1866. Dickens's clear reference to his own long-standing knowledge of workhouse conditions was doubtless recognised at the time as a reference not to his childhood and adolescent years in the street beside the workhouse-which was far from common knowledge in his lifetime-but rather to his famous novel Oliver Twist. His most recent work, Our Mutual Friend (1864-1865), had featured the character Betty Higden-who takes to the road with deliberation, her funeral money sewn into her clothes. ${ }^{74}$ Mrs Higden's manner of avoiding death in the workhouse evidences Dickens's bitter recognition, thirty years after Oliver Twist, of the malign effectiveness of the workhouse system. He designed her trek to demonstrate the lengths to which many selfrespecting poor people were driven in order to escape the abjection of the 'bare life' policies of the New Poor Law, the terror of which was knowingly and purposefully spread well beyond workhouse walls.

The New Poor Law system designedly enforced family fragmentation, regimentation, forced labour, and punitive starvation, inflicting social death ahead of physical death. Conscription for dismemberment after death was a refinement which blatantly equated poverty and murder, the lawful punishment of which for centuries had yielded gallows corpses for dissection. The 1832 Anatomy Act selected its victims for mental torture during life, engendering fear and exacerbating a sense of economic, social, and physical subjugation-humiliation so strong that poor people felt forced to find ways to circumvent the system (such as the mass adoption of burial insurance) or succumb to it. ${ }^{75}$ Many, like Betty Higden, had rather die outdoors than apply to the parish. Those who ended up in the workhouse in old age or infirmity knew they could never escape its protracted death sentence and subsequent dismemberment. In the district in which I grew up in London, the local hospital-which previously had been a workhouse infirmary-was known well into the 1980s simply as the Knacker's Yard.$^{76}$ The bestialising of the poor was thus recognised and characterised by the poor themselves, despite the arrival of the National Health Service over thirty years earlier.

The jumbled human remains buried within the perimeter walls of the workhouse site in Cleveland Street, like those in Gower Street, await their day. Things really can be hidden in plain sight. Yet, buried in life, they can and sometimes do re-emerge vitally after death. 
Dickens, the boy who was raised beside a great London workhouse, pitched his novels actively to resist the cruelty of a system by which those in comfort were invited not to remember the living dead of the workhouse, but rather to dis-member and forget. Dickens would not permit his readers-who had been engrossed by the story of Oliver's starvation, maltreatment, danger and ultimate survival - to forget that the child's mother, dying alone in the workhouse, had qualified as a candidate for dissection. ${ }^{77}$ Like Norfolk Street in Forster's biography of Dickens, the process of her evisceration and dismemberment can now be recognised as a narrative which haunts the text.

\section{WORKS CITED}

\section{Archives}

Katharine Longley Archive, Senate House Library, University of London.

\section{Published sources}

Anon. 'Sermons in Stone.' The Builder, 11.9.1858, 613.

Allen, Michael. Charles Dickens' Childhood. New York: St Martin's Press, 1988.

Allen, Michael. 'New Evidence on Dickens's Grandparents.' The Dickensian 109:489 (2013) 5-20.

Anstruther, Ian. The Scandal of the Andover Workhouse. London: Bles, 1973.

Association For The Improvement of London Workhouse Infirmaries. Report of a Meeting, 3 March 1866. London: Savill and Edwards, 1866.

Aylmer, Felix. Dickens Incognito. London: Rupert Hart-Davis, 1959.

Chadwick, Edwin. 'Circular Letter relative to Workhouse Dietaries.' In: Poor Law Commission. Second Annual Report. London: Her Majesty's Stationery Office, 1836, Appendix 7, 63-66.

Dickens, Charles. Oliver Twist. Originally published in monthly parts, London, February 1837-April 1839 in Bentley's Miscellany. In book form it was originally subtitled 'The Parish Boy's Progress'. Extracts used here are from the Oxford University Press edition of 1949. Oliver Twist in the notes below.

Dickens, Charles. Our Mutual Friend. Originally in monthly parts, London, May 1864November 1865. In book form, Chapman and Hall, January 1865.

Forster, John. [Ley, JWT ed.] The Life of Charles Dickens [originally 2 vols, 1872-4]. London: Cecil Palmer, 1928.

Fredeman, William E. 'A Shadow of Dante.' Victorian Poetry (1982) 217-245.

Green, David R. 'Icons of the New System: Workhouse Construction and Relief Practices in London under the Old and New Poor Law.' The London Journal $34: 3$ (2009) 264-284, doi: https://doi.org/10.1179/030580309X12496474607020.

Holden's Triennial Directory. London: Holden, 1809.

Leary, Patrick. 'How the Dickens Scandal went Viral.' In: Hazel Mackenzie and Ben Winyard (eds.), Dickens and the Mid-Victorian Press, 1850-1870. Buckingham: University of Buckingham Press, 2013, 305-325.

Long, William F. 'Dickens, Macready and the Theatrical Charltons.' Dickens Quarterly 30:4 (2013) 299-309. 
Long, William F. 'Defining a Life - Charles's Youngest Sister, Harriet Ellen Dickens.' The Dickensian 110:492 (2014) 24-34.

Long, William F. and Ruth Richardson. 'Where John and Elizabeth Dickens Buried their Children.' The Dickensian 110:494 (2014) 228-337.

Mbembe, Achille and Libby Meintjes. 'Necropolitics.' Public Culture 15:1 (2003) 11-40. doi: muse.jhu.edu/article/39984.

Merrington, William Robert. University College Hospital and its Medical School: A History. London: Heinemann, 1976.

Nisbet, Ada. Dickens and Ellen Ternan. Berkeley: University of California Press, 1952.

Patten, Robert. 'Whitewashing the Blacking Factory.' Dickens Studies Annual 46 (2015) 1-22. doi: https://doi.org/10.7756/dsa.046.001/1-2.

Pettigrew, Thomas J. The Pauper Farming System: A Letter to the Rt. Hon. Lord John Russell on the Condition of the Pauper Children of St James Westminster as demonstrating the necessity of abolishing the Farming System. London: Rodd, 1836.

Potter, Peter. Plan of the Parish of Saint Marylebone, in the County of Middlesex. London: Potter and Neele, 1820.

Psiropoulis, Brian. 'Hortense is no Esther.' Notes and Queries (2013) 265. doi: https://doi. org/10.1093/notesj/gjt086.

Pugin, Augustus Welby. Contrasts. Salisbury: Pugin, 1836.

Richardson, Ruth. Death, Dissection and the Destitute: A Political History of the Human Corpse. London: Routledge, 1988. [2nd edition, Chicago University Press, 2000].

Richardson, Ruth. 'Young Mr Dickens's Calling Card.' Dickens Quarterly 28:1 (2011) 65.

Richardson, Ruth. Dickens and the Workhouse. Oxford: Oxford University Press, 2012.

Richardson, Ruth. 'The Subterranean Topography of Oliver Twist.' Dickens Quarterly 32:4 (2015) 293-312.

Richardson, Ruth. 'Dickens, Dick and Dido: Oliver Twist and the Opera at Home.' Dickens Quarterly 33:3 (2016) 173-200.

Richardson, Ruth and Brian Hurwitz. 'Jeremy Bentham's Self Image: An Exemplary Bequest For Dissection.' British Medical Journal 295 (1987) 195-198.

Richardson, Ruth and Brian Hurwitz. 'Joseph Rogers and the Reform of Workhouse Medicine.' British Medical Journal 299 (1989) 1507-1510. [Reprinted History Workshop Journal 43 (1997) 218-225].

Rogers, Joseph. In: Thorold Rogers (ed.), Reminiscences of a Poor Law Medical Officer. London: Fisher Unwin, 1889.

Slater, Michael. Charles Dickens. New Haven: Yale University Press, 2009.

Slater, Michael. The Great Dickens Scandal. New Haven: Yale University Press, 2012.

Storey, Gladys. Dickens and Daughter. London: Muller, 1939.

Tomalin, Claire. The Invisible Woman. London: Penguin, 1991.

\section{Websites}

edition.cnn.com/2015/01/23/world/gallery/auschwitz-liberation/index.html https://spitalfieldslife.com/2013/06/09/at-charles-dickens-childhood-home/ spitalfieldslife.com/2017/02/16/an-east-end-murder-a-west-end-grave/ spitalfieldslife.com/2017/07/04/florence-nightingale-in-cleveland-st/ ucl.ac.uk/bentham-project/who-was-jeremy-bentham/auto-icon ucl.ac.uk/news/news-articles/1204/120423-buried-on-campus urbandictionary.com/define.php?term =king $\% 27 \mathrm{~s} \% 20$ college $\% 20$ london 


\section{ABOUT THE AUTHOR}

Ruth Richardson is the author of several books and many academic papers. She is a Londoner, currently Senior Research Fellow at King's College London's Centre for Life-Writing Research, Fellow of the Royal Historical Society, Writer in Residence at the Gordon Museum at Guy's Campus, and Past President of the Dickens Society. She has been an Associate Scholar in the History and Philosophy of Science at the University of Cambridge and Honorary Professor in Humanities and Medicine at Hong Kong University. Her interests lie in the history of bodily appropriation and donation, and in the interaction of medical and lay cultures of bodily understanding.

\section{NOTES}

1 This paper is a developed version of the author's keynote lecture at the Dialogues of the Dead: A day of exploration of life writing $\mathcal{E}$ death conference at the Centre for Life-Writing Research, King's College London, May 24th 2018.

2 While this paper was in press, newly discovered data was published by the Dickens scholar Leon Litvak, concerning Forster's involvement in Dickens's burial in Westminster Abbey. See:https://theconversation.com/charles-dickens-newly-discovered-documents-revealtruth-about-his-death-and-burial-130079. Litvak, Leon. 'Charles Dickens and Westminster Abbey: The Elusive Times Leader of 13 June 1870.' The Dickensian, in press 2020. I am grateful to Professor Litvak for an advance view of this paper.

3 Forster, John [Ley, JWT ed.]. The Life of Charles Dickens [1872-4]. London, Cecil Palmer, 1928. The Appendix containing the text of Charles Dickens's Will appears on pages $857-61$, originally at the back of Forster's third volume.

4 Storey, Gladys. Dickens and Daughter. London: Muller, 1939 featured details of Dickens's relationship with Ellen Ternan recorded in person from Dickens's daughter Kate Perugini.

5 Katharine Longley's extensive investigative researches were provoked by Storey's book, and her findings provided the basis for subsequent works in this field (eg: Claire Tomalin) but remain unpublished in the Archives at Senate House Library, University of London.

6 Nisbet, Ada. Dickens and Ellen Ternan. Berkeley: University of California Press, 1952.

7 Aylmer, Felix. Dickens Incognito. London: Rupert Hart-Davis, 1959.

8 Tomalin, Claire. The Invisible Woman. London: Penguin, 1991.

9 Slater, Michael. The Great Dickens Scandal. New Haven: Yale University Press, 2012.

10 Leary, Patrick. 'How the Dickens Scandal went Viral.' In: Hazel Mackenzie and Ben Winyard (eds.), Dickens and the Mid-Victorian Press, 1850-1870. Buckingham: University of Buckingham Press, 2013 (305-325).

11 Forster, John. In: J. W. T. Ley (ed.), The Life of Charles Dickens [1872-4]. London, Cecil Palmer, 1928 (23-37).

12 Patten, Robert. 'Whitewashing the Blacking Factory.' Dickens Studies Annual 46 (2015) (1-22), doi: https://doi.org/10.7756/dsa.046.001/1-2.

13 Condensed from Forster, John, 1928 (23-37).

14 Ibidem.

15 Patten, Robert, 2015.

16 Allen, Michael. Charles Dickens' Childhood. New York: St Martin's Press, 1988 (18-19). 
17 Long, William and Ruth Richardson. 'Where John and Elizabeth Dickens Buried their Children.' The Dickensian 110:494 (2014) (228-337).

18 Richardson, Ruth. 'Dickens, Dick and Dido: Oliver Twist and the Opera at Home.' Dickens Quarterly 33:3 (2016) (173-200).

19 Holden's Triennial Directory. London: Holden, 1809 (39).

20 Allen, Michael, 1988 (18-19).

21 Allen, Michael. 'New Evidence on Dickens's Grandparents.' The Dickensian 109:489 (2013) (5-20).

22 Long, William F. 'Defining a Life - Charles's Youngest Sister, Harriet Ellen Dickens.' The Dickensian 110:492 (2014) (24-34).

23 Long, William F. 'Dickens, Macready and the Theatrical Charltons.' Dickens Quarterly 30:4 (2013) (299-309).

24 Forster, John, 1928 (2).

25 Richardson, Ruth. 'The Subterranean Topography of Oliver Twist.' Dickens Quarterly 32:4 (2015) (305-306).

26 This Table presents an improved version of 'Where Dickens lived before "Boz", which appeared in Richardson, Ruth. Dickens and the Workhouse. Oxford, Oxford University Press, 2012 (310-311). Dickens's own long-term family homes at Devonshire Terrace, Marylebone (1839-1851) and Tavistock House, St Pancras (1851-60) each stood within a short walk of the same parish boundary.

27 Fredeman, William E. 'A Shadow of Dante.' Victorian Poetry (1982) (217-245).

28 Most noticeably for Sketches by Boz and Barnaby Rudge, but other works, too. See Richardson, Ruth, 2012 (Chapter 9 passim).

29 Potter, Peter. Plan of the Parish of Saint Marylebone, in the County of Middlesex. London: Potter and Neele, 1820.

30 Nisbet, Ada, 1952 (48-9). See also Slater, Michael. Charles Dickens. New Haven: Yale University Press, 2009 (457).

31 Richardson, Ruth and Brian Hurwitz. 'Joseph Rogers and the Reform of Workhouse Medicine.' British Medical Journal 299 (1989) (1507-1510). [Reprinted History Workshop Journal, 43 (1997) (218-225)]. There is now a blue plaque on Rogers's old home at 33 Dean Street, Soho.

32 The workhouse building was an important annexe to the Middlesex Hospital. The healthcare history of the building is complex. The Cleveland Street Workhouse had become a Poor Law Infirmary and a Poor Law children's hospital before its acquisition by the Middlesex Hospital in the 1920s. By this acquisition the Hospital was able to rebuild itself. The Infirmary was completely modernised before the Hospital decanted itself into it in two great tranches. The building initially housed the Middlesex Hospital's Surgical and Maternity wards, and subequently its Out-Patients' Department. The Middlesex Hospital and this Annexe served Londoners under the auspices of the National Health Service from 1948 to the closure of the Hospital in 2005. See Richardson, Ruth. 2012 (16-18, 73-76, 237-46, 290-300).

33 The blue plaque now attached to the house was unveiled on June 8th 2013 by Dickens's great-great-great-grandaughter, Lucinda Hawksley, on behalf of the Friends of Cleveland Street Workhouse. It was privately funded by one of the Friends, Dan Calinescu, of Toronto, and endorsed by The Dickens Fellowship. The Gentle Author's account of the event is here: https://spitalfieldslife.com/2013/06/09/at-charles-dickens-childhood-home/.

34 Richardson, Ruth. 'Young Mr Dickens's Calling Card.' Dickens Quarterly 28:1 (2011) (65).

35 Richardson, Ruth, 2012 (190-91).

36 Idem (273-274).

37 Psiropoulis, Brian. 'Hortense is no Esther.' Notes and Queries (2013) (265). doi:10.1093/ notesj/gjt086. 
38 Richardson, Ruth. 'Florence Nightingale in Cleveland St.' Spitalfields Life website, 4 July 2017, spitalfieldslife.com/2017/07/04/florence-nightingale-in-cleveland-st/. Date accessed: 13 August 2019. The folly of demolishing perfectly serviceable Nightingale wards only became evident to some people during the COVID outbreak of 2020, when fresh-air ventilated wards would have been highly valuable. The same could be said of other hospitals on Miss Nightingale's plan elsewhere in the country.

39 Richardson, Ruth, 2012 (74-76).

40 Green, David R. 'Icons of the New System: Workhouse Construction and Relief Practices in London under the Old and New Poor Law.' The London Journal 34:3 (2009) (264284): doi:10.1179/030580309X12496474607020.

41 Pettigrew, Thomas J. The Pauper Farming System: A Letter to the Rt. Hon. Lord John Russell on the Condition of the Pauper Children of St James Westminster as demonstrating the necessity of abolishing the Farming System. London: Rodd, 1836.

42 Richardson, Ruth, 2012 (282-84).

43 Oliver Twist, Chapter 2.

44 Mbembe, Achille and Libby Meintjes. 'Necropolitics.' Public Culture 15:1 (2003) (11-40). doi: muse.jhu.edu/article/39984.

45 Oliver Twist, Chapter 4.

46 Anon. 'Sermons in Stone.' The Builder, 11.9 .1858 (613).

47 'Liberation of Auschwitz.' CNN, 14 April 2015, https://edition.cnn.com/2015/01/23/ world/gallery/auschwitz-liberation/index.html. Date accessed: 13 August 2019.

48 Richardson, Ruth, 2012 (214-20, 237-42).

49 Chadwick, Edwin. 'Circular Letter relative to Workhouse Dietaries.' In: Poor Law Commission. Second Annual Report. London: Her Majesty's Stationery Office, 1836 (Appendix 7, 63-66).

50 Anstruther, Ian. The Scandal of the Andover Workhouse. London: Bles, 1973.

51 Richardson, Ruth, 2012 (220-21).

52 Richardson, Ruth, 2016 (185).

53 Mbembe and Meintjes, 2003 (11-40).

54 Oliver Twist, Chapters 2 and 3. Oliver is kept in the dark, in solitary confinement, in a bare cell without any covering in cold weather, beaten with a cane, flogged in front of an assembled audience of workhouse staff and inmates, and kicked. It is not clear from the book how long this kind of punitive maltreatment continued, but it seems protracted. He narrowly avoids being 'apprenticed out' to a brutal chimney sweep (which was oftentimes a form of 'accidental' death sentence for children) and is eventually placed with the undertaker Sowerberry, where he has to sleep among the coffins. Edwin Chadwick at the Poor Law Commission's headquarters favoured sending 'disorderly and refractory' children to work in factories in the Manufacturing districts in the north of England. See Richardson, Ruth, 2012 (242-43).

55 Oliver Twist, Chapter 17.

56 Richardson, Ruth, 2016 (173-200).

57 Pugin, Augustus Welby. Contrasts. Salisbury: Pugin, 1836.

58 'Contrasted Residences for the Poor' in Pugin, Augustus Welby, 1836.

59 Oliver Twist, Chapter 4.

60 Oliver Twist, Chapter 53. The point is made in the final paragraph.

61 Richardson, Ruth, 2015 (293-312).

62 Glass lights in the pavement outside the building indicate that the tunnel passed near the Master's House. They are currently (2020) obscured by builders' boards.

63 Richardson, Ruth, 1988 (Chapter 10 passim).

64 'King's College London.' Urban Dictionary, https://www.urbandictionary.com/define. php?term=king\%27s\%20college\%20london. Date accessed: 13 August 2019. 
65 'Buried Victorian anatomical teaching collection put on display' (23 April 2012): http:// www.ucl.ac.uk/news/news-articles/1204/120423-buried-on-campus. Date accessed: 13 August 2019.

66 Richardson, Ruth and Brian Hurwitz. 'Jeremy Bentham's Self Image: An Exemplary Bequest For Dissection.' British Medical Journal 295 (1987) (195-198).

67 'Auto-Icon.' UCL, https://www.ucl.ac.uk/bentham-project/who-was-jeremy-bentham/ auto-icon. Date accessed: 13 August 2019.

68 Merrington, William Robert. University College Hospital and its Medical School: A History. London: Heinemann, 1976. The housing of the UCL Medical School, and of the Anatomy Department in a building separate from both the University (where lectures were delivered) and the Hospital (where clinical teaching took place) did not occur until the twentieth century at UCL, so it seems most likely that dissections were done in the basement levels of the old Hospital, close to the mortuary, or dead house.

69 Richardson, Ruth, 1988 (Chapter 10 passim).

70 'Buried Victorian anatomical teaching collection put on display.' UCL, 23 April 2012: http://www.ucl.ac.uk/news/news-articles/1204/120423-buried-on-campus. Date accessed: 13 August 2019.

71 Rogers, Joseph [Rogers, Thorold ed.] Reminiscences of a Poor Law Medical Officer. London: Fisher Unwin, 1889 (13-14). See also Richardson, Ruth, 2012 (240) concerning the parish undertaker, Mr Dix.

72 They included the 'Italian Boy', the last victim of the London Burkers, Bishop and Williams, the ruffians who in 1831 were hanged for murdering him to sell his body for dissection, and whose case at the Old Bailey Charles Dickens is said to have reported upon. See: Richardson, Ruth. 'An East End Murder and A West End Grave.' Spitalfields Life, 16 February 2017, spitalfieldslife.com/2017/02/16/an-east-end-murder-a-west-endgrave/. Date accessed: 13 August 2019.

73 Association For The Improvement of London Workhouse Infirmaries. Report of a Meeting, 3 March 1866. London: Savill and Edwards, 1866.

74 Dickens, Charles. Our Mutual Friend, Chapter 8.

75 Richardson, Ruth, 1988 (275-80).

76 A knackers' yard was where broken-down horses were taken to be rendered into glue, horse hair, bone-meal, etc.

77 Richardson, Ruth, 2015 (293-312). 